\title{
THE CONTRIBUTION OF THE RELIGION OF THE COLONIAL PERIOD TO THE IDEALS AND LIFE OF THE UNITED STATES *
}

$\mathrm{T}$

HE Great Seal of the United States, designed in the early days of the Republic, has on it symbolism whose significance is often overlooked. On one side is an eagle which grasps with one talon a branch and with the other a sheaf of arrows. Above its head are "E Pluribus Unum" and thirteen stars for the original states bound together in one nation. The other side has on it an unfinished pyramid. The foundation bears the number MDCCLXXVI. Above the pyramid is the eye of God flanked by the words "Annuit Coeptis," namely, "He smiles on the undertakings." Underneath is the phrase "Novus Ordo Seculorum," meaning "New Order of the Ages." Here succinctly is the vision which inspired the founding fathers of the new nation. The thirteen colonies had become one, prepared to face together the exigencies of the future, whether for preservation in selfdefense or for cooperation in the arts of peace. Here was an attempt at building something novel in the history of mankind-a new and ordered structure. That structure, as yet incomplete, was based upon the Declaration of Independence, with its best-remembered phrases: "We hold these truths to be self-evident, that all men are created equal, that they are endowed by their Creator with certain inalienable rights, that among these are life, liberty, and the pursuit of happiness-that to secure these rights, governments are instituted among men, deriving their just powers from the consent of the governed." Here is "the American dream." As "four score and seven years" later Abraham Lincoln even more briefly described it, the new nation was "conceived in liberty and dedicated to the proposition that all men are created equal" and its success or failure was a test whether "government of the people, by the people, for the people " could "long endure." To that dream faith in God, in His creative activity, and in His sovereignty was basic.

Although Jefferson was the framer of the Declaration of Independence,

* Kennetb Scott Latourette is Professor Emeritus of the Missions and Oriental History at Yale University. In 1948 he was President of the American Historical Association and in 1945, of the American Society of Church History. Among his important publications are: The Development of Cbina (6th ed.; 1946); The Cbinese, their bistory and culture (2 vols.; 3rd ed.; 1946); $A$ History of the expansion of Christianity (7 vols.; 1937-1945). Address: 409 Prospect Street, New Haven, Connecticut. 
the ideas in it were not primarily his. They came from convictions which were widespread in the Thirteen Colonies. They were generally accepted by those who fought for them because they put into easily remembered slogans what a large proportion of the population had long believed. That was also true of the Latin phrases on the Great Seal and of Lincoln's Gettysburg Address. Indeed, it was the American dream which nerved and sustained Lincoln in his leadership of the Union during the agony of the Civil War and to which he appealed as he sought to call the nation to the prodigious sacrifice entailed in carrying the struggle through to its stern but triumphant end.

Here, too, was the dream which inspired the Constitution of the United States. It was given expression not only in the structure set up by the original document but it also was the source of the first ten amendments to the Constitution, a kind of "bill of rights," and of the thirteenth, fourteenth, and fifteenth amendments which abolished slavery and sought to insure to the freedmen and their descendants rights and opportunities equal to those of the white members of the nation.

The American dream has again and again been embodied in verses which have sung their way into the hearts of millions. They have been popular because, like the Declaration of Independence and the Gettysburg Address, they have put into words the common faith and hope. They are born of the American ethos. Such are: "My country, 'tis of thee, sweet land of liberty, of thee I sing . . . Land of the pilgrim's pride . . . From every mountain side let freedom ring. . . . Our fathers' God to Thee, author of liberty, to Thee we sing. Long may our land be bright with freedom's holy light. Protect us by Thy might, Great God, our King." Such, too, are the famous lines by Katherine Lee Bates: " $O$ beautiful for pilgrim feet, whose stern impassioned stress a thoroughfare for freedom beat across the wilderness. America, America, God mend thy every flaw, confirm thy soul in self-control, thy liberty in law. ... O beautiful for patriot dream that sees beyond the years thine alabaster cities gleam undimmed by human tears. America, America, God shed His grace on thee, and crown thy good with brotherhood from sea to shining sea." Such, also, are the lines written to commemorate the two hundredth anniversary of the founding of New Haven Colony which merged to form one of the Thirteen, Connecticut: " $O$ God beneath thy guiding hand our exiled fathers crossed the sea; and when they trod the wintry strand, with prayer and psalm they worshipped Thee. . . . Laws, freedom, truth, and faith in God came with those exiles o'er the waves; and 
where their pilgrim feet have trod the God they trusted guards their graves."

That the dream incorporated in these words, whether of prose or in verse, was of Christian origin is abundantly clear. The Christian influence came through Protestantism, and much although not all of it was through what in the inclusive sense of that term was known as Calvinism, mainly in the form of Puritanism and the movements which issued directly from it, were akin to it, or were profoundly influenced by it. The dream found embodiment not only in government and politics but also in many other phases of the ideals and life of the United States.

One of the most vividly remembered features of the history of the Thirteen Colonies is that the settlements which brought them into being were made in part by Protestant minorities which dissented from the state churches of Europe and came to the New World to escape persecution and there to worship God and order their lives, both individually and collectively, as they believed that the Christian faith required. That motive was especially prominent in the first settlements in New England and Pennsylvania, but it was also present in smaller groups in all the other colonies. The Protestant refugees included Puritans and Independents who eventually coalesced to constitute the Congregationalists, Baptists, Quakers, Huguenots, and several German groups, among them the Moravians. In many the economic motive was strong. In some it was outstanding, as, for example, among the Presbyterians from North Ireland. But the Scotch-Irish immigration was also impelled in part by the desire to be freed from the constraint to support the Anglican Established Church and to conform to it. While the state churches were represented-the Church of England, Lutherans from Germany and Scandinavia, Reformed from the Netherlands and Germany, and a few from the Church of Scotland (Presbyterian)-they were much weaker than in Europe. The Reformed Church was the state church of the infant New Amsterdam before that colony was transferred to the English and became New York. The Church of England was established in Maryland, Virginia, North Carolina, South Carolina, and Georgia, and efforts, of dubious success, were made to bring about its establishment in New York, but it was severely handicapped by the lack of a resident episcopate. The Swedish Lutheran congregations on the Delaware long were connected with the Church of Sweden. ${ }^{1}$ Roman Catholics constituted only small minorities, even in

\footnotetext{
${ }^{1}$ William Warren Sweet, Religion in Colonial America (New York, 1942), passim.
} 
Maryland, founded though it was by their fellow-believer, Lord Baltimore. ${ }^{2}$

However, the primary motive which impelled the large majority of the immigrants to leave their mother lands for the Thirteen Colonies was not religious but economic. As a result only a very small proportion became members of churches in their new homes. They were Protestant by tradition, but in the Old World their conformity to the state churches had been more a matter of social convention enforced by law than of deep religious conviction. Even by 1800 after the Great Awakening and later revivals had brought many into church membership, a scarce 6.9 per cent, or about one in fourteen of the population seem to have been members of churches. ${ }^{3}$ The majority were in danger of de-Christianization.

Yet from the loyal minority issued the strains which were dominant in inspiring the American dream. Important influences came by way of the Enlightenment, but, being chiefly from English sources, they were deeply indebted to John Locke, who was reared in the Puritan tradition and continued to conform to the Church of England, and from Deism, which had its origin and early formulation in English Protestantism.

We do well to remind ourselves of the distinctive genius of Protestantism, for it has been reflected in the ethos of the United States and its people. In common with the other great branches of Christianity it stresses faith in God as revealed and acting through Christ for man's salvation, the Bible divinely inspired as a record of that salvation, and the Church as the body of Christ, made up of the redeemed in heaven and on earth. Peculiar to it has been salvation by faith alone, the priesthood of all believers, and, as a corollary, the right and duty of individual judgment, but which seeks to give due recognition to what others and the Church as a whole have said in interpreting the Scriptures and God's action in Christ. Luther's stand at the Diet of Worms was characteristic. When, after recognition of salvation through faith alone-sola fide-had brought peace to his anguished soul, he was confronted by the combined authority of Church and state and was asked to recant

For the Church of England see Sweet, op. cit., pp. 28-45. On the Dutch Reformed, see Sweet, op. cit., pp. 192-202. On the Swedish Lutherans see Sweet, op. cit., pp. 203-205.

"Sweet, op. cit., pp. 167-184; John Tracy Ellis, American Catbolicism (The University of Chicago Press, 1956), pp. 19-39.

${ }^{3}$ Herman C. Weber, 1933 Edition Yearbook of American Cburches (New York, 1933), p. 750. On some other estimates see Anson Phelps Stokes, Cburch and State in the United States (3 vols.; New York, 1950), I, 229. 
what ran counter to the teachings of the Roman Catholic Church, he declared: "Unless I am convicted by Scriptures and plain reason-I do not accept the authority of Popes and Councils, for they have contradicted each other-my conscience is captive to the Word of God. I cannot and will not recant anything, for to go against conscience is neither right nor safe. God help me. Amen." " In somewhat different terms Luther reiterated this conviction in his pamphlet Concerning Christian Liberty: "A Christian man is the most dutiful servant of all and subject to every one." " Luther did not follow these principles to their logical conclusion. Indeed, he drew back, appalled, from the extremes to which some were pushing them.

Yet in the attitude put into these trenchant words is the source of much of American democracy, whether in government, in other forms of social structure, in thought, or in education. Here, for better or for worse, is the kind of individualism which the American dream has sponsored. Protestantism assigns great worth to the individual as created in the image of God and cherishes the possibility of the individual becoming, through God's grace, a child of God and a member of the Church. This it holds in common with the Catholic form of the faith. It dissents from the Roman Catholic Church in holding to sola fide, the priesthood of all believers, and the kind of liberty set forth by Luther in word and, on occasion, in action. From the combination of what is common to the Catholic tradition and what is distinctive of the Protestant dissent comes the kind of democracy seen in the United States.

As we have suggested, the channel through which Protestantism was the source of that democracy and, with it, of the American dream, was Calvinism. ${ }^{\circ}$ John Calvin did not fully implement the Protestant principles. For example, he placed restraints on religious freedom and did not prevent the burning of Servetus. Yet he held him to be a tyrant who ruled against the consent of the governed and abused his power. ${ }^{7} \mathrm{He}$ also sought to bring to realization the vision of a holy commonwealth in which the pulpit would be free from control by the civil magistrate and in which education would be given an important place. ${ }^{8}$ Here he was giving a Protestant form to what had been inherited

\footnotetext{
‘ Roland H. Bainton, Here I Stand. A Life of Martin Lutber (New York, 1950), p. 185.

${ }^{5}$ Lutber's Primary Works... edited by Henry Wace and C. A. Buchheim (London, 1896), p. 256.

- On Calvinism as a source of American democracy see A. Mervyn Davies, Foundation of American Freedom (New York, 1955), passim.

"Ibid., p. 48.

${ }^{8}$ Ibid., Pp. 44, 45, 50, 55.
} 
from the Catholic Church of the Middle Ages. Yet what was called Calvinism was not the elongated image of Calvin. It was a growing organism to which other thinkers also contributed. In England it helped to shape Puritanism, the Independents, the majority wing of the Baptists, and, by a reaction from it, the Quakers. It was potent in the Reformed churches of the Netherlands, Germany, and France, and in the Presbyterianism of the British Isles. Through these channels it became the most pervasive and influential strain in the Protestantism of the Thirteen Colonies and thus in inspiring and giving form to the American dream.

Calvinism was especially prominent in New England. It is no accident that the three hymns we have mentioned-"America," "America the beautiful," and "O God beneath Thy guiding hand" (also known as "The Pilgrim Hymn")-came from the Calvinist heritage of New England. "America" was written by Samuel Francis Smith, a native of Boston, a Baptist clergyman, during his student days in Andover Theological Seminary, an institution founded by Calvinist Congregationalists." The author of "America the beautiful" was Katherine Lee Bates, daughter and granddaughter of New England Congregational ministers and the poem first appeared in The Congregationalist. ${ }^{10}$ " $\mathrm{O}$ God beneath Thy guiding hand" was composed by Leonard Bacon, long minister of the First Church of Christ (Congregational), the mother congregation of New Haven, Connecticut, as part of the bicentennial celebration of the founding of that Puritan colony. ${ }^{11}$

The men who shaped the beginnings of New England were impelled by the dream of realizing there the kingdom of which God is King. Richard Baxter (1615-1691) had wished to turn the British Commonwealth into a Holy Commonwealth, a theocracy whose members would be ruled by the Sovereign God and in which the officers of the Church and state would be chosen by electors who had owned the baptismal covenant and taken the Triune God as their only God. In that commonwealth holiness would have the principal honor and encouragement. ${ }^{12}$ Leaders among those who came to New England despaired of seeing the Holy Commonwealth realized in the Old World, for there "the fountains of learning and religion are so corrupted as ...

\footnotetext{
'Dictionary of American Biography, XVII, 342, 343.

${ }^{10}$ Dictionary of American Biography, XXI, 59.

${ }^{11}$ Theodore Davenport Bacon, Leonard Bacon, A Statesman of the Church (New Haven, 1931), p. v.

${ }^{12}$ Herbert Wallace Schneider, The Puritan Mind (New York, 1930), pp. 14-16. On the theory of covenant in Church and state see Perry Miller, The New England Mind: the Seventeentb Century (New York, 1939), pp. 398 ff., 432 ff.
} 
most children ... are perverted, corrupted, and utterly overthrown by the multitude of evil examples," and believed that "the Church hath no place left to fly into but the wilderness." ${ }_{13}$ Again and again the early Puritan settlers of Massachusetts affirmed their faith that they were divinely chosen and that God had sifted a whole people to choose the best grain for New England. ${ }^{14}$ At the outset government in Church and state was in the hands of the "saints"-those who had had the personal experience of God's saving grace in Christ.

The earliest New England was not a democracy as the United States later interpreted that word. Suffrage was limited to church members and church membership was confined to the "saints." Nor did the largest of the New England colonies, Massachusetts, have religious tolerance. Dissenters from the "standing order" were persecuted, notably Quakers and Baptists.

However, the trend in New England, arising from religious conviction, was in the direction of democracy. Puritanism, which sought to cleanse the state church from what it regarded as corruption, moved towards the Independents who founded Plymouth colony and who represented the idea of a "gathered church," independent of the state and bound together by a covenant in a church whose only head was Christ. Here was the source of the Congregationalism which prevailed in New England and which generally became Presbyterianism when its members settled outside New England. Thomas Hooker (1586-1647) did much to give Congregationalism a major impulse and to lead it toward democracy. As a refugee from Archbishop Laud's rule in the Church of England he fled to Holland and then to Massachusetts Bay. There as pastor in the later Cambridge he was restive under the Puritan oligarchy, dissented from the limitations of the suffrage to church members, and led a company westward which founded Hartford, the nucleus of Connecticut. Under his inspiration the new colony, in response to principles which he enunciated in a sermon on May 31, 1638 , that "the foundation of authority is laid, firstly, in the free consent of the people," that "the choice of public magistrates belongs unto the people by God's own allowance," and that "they who have the power to appoint officers and magistrates, it is in their power also to set the bounds and limitations of the power and place to which they have called them," adopted a structure of government in which the franchise was conditioned neither by a property qualification nor a

${ }^{13}$ John Winthrop, quoted in George M. Stephenson, The Puritan Heritage (New York, 1952), pp. 29, 30.

${ }^{14} \mathrm{H}$. Richard Niebuhr, The Kingdom of God in America (Chicago, 1937), p. 8. 
religious test. The Fundamental Orders of Connecticut, drafted in response to Hooker's sermon, have been called "the first written constitution of modern democracy." ${ }^{15}$ Congregationalism moved in that direction.

Another channel through which New England Protestantism flowed to contribute to the American dream was Roger Williams (c. 16031684) and Rhode Island, the colony which he founded. ${ }^{16}$ Teacher of the Puritan church in Salem, he was expelled from that post by the authorities of Massachusetts for asserting that the state could not properly have jurisdiction over the consciences of men, that the royal patent could not convey just title to the land held by the colonists, but that this should be bought from the Indians, and that the civil magistrate could not properly require an oath of an unregenerate man. Befriended by the Indians, he went southward, founded Providence, received baptism from an Anabaptist, organized what is usually regarded as the first Baptist church in America, and after a few months became what was then called a Seeker. In 1643 he obtained a charter for what he called the Providence Plantations on the Narragansett Bay, eventually known as Rhode Island. From the beginning, Providence had no established church but recognized freedom of conscience. Williams also sought to create a government which would heed the popular will and provide a place of opportunity for " such as were destitute." $\mathrm{He}$ consistently stood for "liberty and equality, both in land and government." ${ }^{17}$ Although Rhode Island did not fully live up to the purposes of its founder, it embodied ideals which were to contribute to the later United States. Partly because of Rhode Island's toleration, Jews prospered in the colony, notably in Newport.

Still another channel through which the extreme wing of Protestantism contributed to the American dream was the Quakers, and especially William Penn (1644-1718).$^{18}$ Although they were minorities, even in Pennsylvania, the Friends were represented in most and perhaps all the colonies. Some owned slaves, but the consciences of many

\footnotetext{
${ }^{15}$ Vernon Louis Parrington, The Colonial Mind 1620-1800 (New York, 1927), pp. 53-62; Ralph Barton Perry, Puritanism and Democracy (New York, 1944), pp. 195, 196.

${ }^{16}$ James Ernst, Roger Williams, Nerv England Firebrand (New York, 1932), passim; James Ernst, The Political Thought of Roger Williams (Seattle, 1929), passim; Samuel Hugh Brockunier, The Irrepressible Democrat, Roger Williams (New York, 1940), passim; Parrington, op. cit., pp. 62-75; Perry, op. cit., 349-353.

${ }^{17}$ Brockunier, op. cit., pp. $101,102$.

${ }^{18}$ Edward Corbyn Obert Beatty, William Penn as Social Pbilosopher (New York, 1939), passim; Rufus M. Jones, The Quakers in the American Colonies (London, 1923), passim.
} 
were tender on the question, and from them came most of the pioneers of the anti-slavery movement. They also believed in dealing justly with the Indians and had an enviable record of peaceably arranging their relations with them. To William Penn the colony which he founded and which bore his name was a "holy experiment." Penn was a vigorous champion of toleration and sought to make Pennsylvania a haven for persecuted minorities. The basic laws of the colony (1682) accorded religious liberty to "all persons living in this province who confess and acknowledge the one Almighty and Eternal God to be the Creator, Upholder, and Ruler of the world" and declared that they should not "be compelled at any time to frequent or maintain any religious worship, place, or ministry thereof." But toleration of atheism was not included. ${ }^{19}$ In spite of this restriction, no other of the Thirteen Colonies attracted as many racial and religious groups. English, Dutch, Swedes, Germans, Irish, Welsh, and Scotch-Irish came, and a large variety of groups subject to persecution on the other side of the Atlantic were represented.

A further contribution of radical Protestantism to the ethos of the United States was through the Great Awakening. ${ }^{20}$ The Great Awakening was the kind of popular religious movement which embodied the salvation by faith alone which was distinctively Protestant and which was accompanied by the individual experience of conviction of $\sin$ followed by repentance, commitment to Christ, and the joy of forgiveness and salvation which was found mainly in Pietism, Puritanism, and Evangelicalism. It began in 1720 among the Dutch settlements in the Raritan Valley of New Jersey and spread throughout the colonies, sometimes by contagion from the New Jersey movement, and partly independently. Jonathan Edwards was an outstanding leader in New England in an awakening which began in Northampton in 1734. In the 1730's John and Charles Wesley were in Georgia and while after a few months they left that colony, discouraged, from a later perspective it was clear that they had contributed to the movement. A companion of the Wesleys, George Whitefield, first came to Georgia in 1738 at the suggestion of John Wesley, and with his pro-

\footnotetext{
10 Beatty, op. cit., pp. 159-161.

${ }^{20}$ Joseph Tracy, The Great Awakening: A History of the Revival of Religion in the Time of Edwards and Whitefield (Boston, 1842), passim; Wesley M. Gewehr, The Great Awakening in Virginia, 1740-1790 (Durham, N.C., 1930), passim; Arthur Cushman McGiffert, Jr., Jonathan Edwards (New York, 1932), passim; Thomas Cuming Hall, The Religious Background of American Culture (Boston, 1930), pp. 147-160; Sweet, op. cit., pp. 271-318; George Leon Walker, Some Aspects of Religious Life in Nerw England with Special Reference to the Congregationalists (New York, 1897), Pp. 83-125.
} 
found conviction and moving oratory, through repeated visits and wide travel contributed to the Awakening from Georgia to New England. Other preachers of lesser note spread the movement. The Great Awakening not only brought fresh vigor to existing churches and stimulated thousands of their members to more earnest Christian living, it also reached thousands of the partially de-Christianized who constituted the majority of the population, swelled the membership of existing churches, and led to the multiplication of new congregations. Its effects were felt chiefly among the Congregationalists, Presbyterians, and Baptists. Baptists especially increased in numbers.

The Great Awakening was the precursor of the revivals which became characteristic of much of the Protestantism of the United States. Largely although not entirely through them the proportion of the population enrolled in the churches has mounted fairly steadily. They have contributed particularly to the growth of denominations which are either minorities or non-existent in Europe-notably the Baptists and Methodists but also the Congregationalists, Presbyterians, Disciples of Christ, the several denominations bearing the simple name of Christian, and to the United Brethren and its kindred Evangelical Association, now merged in the Evangelical United Brethren in Christ. In some of these denominations the democratic element is strong. It is particularly prominent in the largest of the denominational families, the Baptists. The Great Awakening and the subsequent revivals stressed both individual conversion and a sense of social responsibility. From them issued major philanthropic movements-among them home and foreign missions, a great impetus to the movements to abolish Negro slavery and to curb intemperance in the use of alcoholic beverages, many schools, including colleges, efforts to promote peace between nations, and various forms of service to the underprivileged. Both the individualism and the co-operation in philanthropy have been features of the ethos of the United States, embodiments of the American dream.

A major contribution to the democracy of the United States and to other aspects of the American dream came from Puritanism by way of John Locke. John Locke (1632-1704) was spiritually a child of Puritanism. He reacted against some features of it, including the debates, often bitter, between the several forms of Protestantism which had characterized the period of the early Stuarts and the Commonwealth. Locke has been remembered by philosophers chiefly for his Essay Concerning Human Understanding, in which he endeavored to determine the certainty and adequacy of human knowledge. But his 
effect on the future United States was mainly political and religious. He held that the people are sovereign and have the right to govern themselves in whatever way seems to them to make for the common good. He maintained that there are natural rights, among them property and personal freedom. He insisted that government is properly a form of contract into which the people enter with those who govern them, but that the form of the contract may be modified by the people to meet changing circumstances. Locke was deeply religious. He believed that he had demonstrated through philosophy the existence of God and the dependableness of "natural" religion. He also devoutly held to revelation, had a profound reverence for the Bible, and sought to allay the conflicts between rival sects by going back to the original Christianity and to disentangle the essentials of the faith as set forth in the Gospels from the later and to him debatable accretions. $\mathrm{He}$ favored the establishment of religion, but only on condition that it should be for the purpose of promoting goodness and so broadly based on the simplicity of the Gospels that it would be comprehensive and give no excuse for nonconformity. He was against the toleration of atheism and the Roman Catholic Church. As to the latter, he held that it required obedience to a foreign sovereign and determined arbitrarily what the Christian must believe. His was a religion and ethics of "common sense" and had a wide influence in the Thirteen Colonies. His political and religious views entered into the Declaration of Independence, the Constitution of the United States, and the constitutions of several of the states. ${ }^{21}$

Locke owed part of his influence to the fact that he was reinforcing what had come and was coming from a number of other sources. Among them were the Cambridge Platonists, who were clearly Protestant. They contributed, although unintentionally, to the eighteenthcentury confidence in common sense in religion and utility in morals. ${ }^{22}$ Such Puritans as John Milton made their influence felt. Deism, at the outset from English Protestantism, was potent. For example, John Toland, in his Chistianity not Mysterious (1696) which shared in the rise of Deism, was indebted to Locke and carried the latter's thought further. ${ }^{23}$ As Deism spread to the continent of Europe and contributed

\footnotetext{
${ }^{21}$ Ernest Sutherland Bates, American Faith: Its Religious, Political, and Economic Foundations (New York, 1940), pp. 240-242; Davies, op. cit., pp. 212-214; Perry, op. cit., pp. 126, 127, 184-187; G. R. Cragg, From Puritanism to the Age of Reason (Cambridge University Press, 1950), pp. $114 \mathrm{ff}$.

${ }^{22}$ Cragg, op. cit., pp. $37 \mathrm{ff}$.

${ }^{23}$ Ibid., Pp. $136 \mathrm{ff}$.
} 
to the Enlightenment, its effect, through continental writers who were read in the Colonies and the young United States, was important. ${ }^{24}$

Some of the theories of government propounded by Locke were expounded in sermons in New England. Either independently of him or encouraged by what he wrote, convictions similar to his on the origin and proper function of the civil state were again and again put forward by New England clergy in the eighteenth century. Ministers were important in colonial New England and, especially before the age of newspapers, their preaching was a major instrument in forming public opinion. We hear in a sermon of 1669 that "power of civil rule, by men orderly chosen, in God's ordinance," and in a slightly earlier sermon, in 1663, "the end of all civil government and administration . . i is the public and common good." ${ }^{25}$ The New England clergy declared that, though ordained by God, civil government did not come directly from Him, but mediately through the people and had been founded on compact. Compact was important in their theology and was viewed as the foundation of church government and as at the root of all God's dealings with men: in the seventeenth and eighteenth centuries they accepted as axiomatic the theory of social compact and used it to support the rights of the people both in Church and state. ${ }^{26}$ In 1717, in defying Andros, the royal governor of Massachusetts, one of the clergy, John Wise, insisted that in his natural state man enjoyed, as his right, a liberty which made him subject to no other human being, and that all men are equal in authority and that each has the right to judge for himself what is most conducive to his happiness and welfare. He declared that the people might delegate part of that power to others, but they were, of right, free to form a new commonwealth, and that a democracy "is a form of government ... most agreeable to the just and natural prerogative of human beings." ${ }^{27}$ The majority of Congregationalists and all Baptists believed that each local church had the full power to choose its officers and manage its own affairs. Here in theory was a pure democracy and, while not always perfectly realized, its implementation in ecclesiastical matters was a training ground for similar convictions and practices in the political arena. Many New England ministers pointed out that freedom entailed responsibility, and that the majesty of law must be revered by people as well as rulers if the liberties of the people were to be secured. ${ }^{28}$ Yet on

\footnotetext{
24 Perry, op. cit., pp. 184-197; Parrington, op. cit., pp. 189, 190.

${ }^{25}$ Alice M. Baldwin, The New England Clergy and the American Revolution (Durham, N. C., 1928), pp. 22-23.

${ }^{26}$ lbid., pp. 24, 25.

${ }^{27}$ Ibid., pp. 28, 29. ${ }^{28}$ Ibid., pp. 32 ff.
} 
the eve of the War of Independence Jonathan Mayhew, something of a firebrand, was preaching that "disobedience is not only lawful but glorious". against those who "enjoin things that are inconsistent with the demands of God." ${ }^{29}$ Significantly, James Otis, one of the early Boston radicals in resistance to British rule, drew his inspiration from Mayhew. ${ }^{30}$

However, the Puritans were clear that the kingdom belonged only to God and that all authority stemmed from Him. They were, therefore, opposed, as were other radical Protestant groups, to claims of absolute popular sovereignty such as found expression in the French Revolution and in some other political developments of the eighteenth century and as they would have been to such movements as Marxism in the nineteenth and twentieth centuries. ${ }^{31}$

In view of this brief survey, may we attempt to summarize the contribution of the religion of the colonial period to the ideals and life of the United States?

First of all, we must again remind ourselves that the contribution was almost entirely through Protestantism, and more from extreme Protestantism than from the majority forms established by the state on the other side of the Atlantic.

Second, we must note that a widespread conviction was cherished that the founding of the new nation was under God and by the inspiration of God. Here was an assumption which, although it came chiefly through Protestantism, was not exclusively Protestant: all Christians, of whatever branch of the Church, could share in it. It is seen in the Great Seal of the United States. Coins bear the inscription: "In God we trust." Although not a church member, but in his Presidency a regular attendant at a Presbyterian church, in his famous Gettysburg address Abraham Lincoln had appealed to his fellow countrymen to " highly resolve ... that this nation, under God, shall have a new birth of freedom." A more recently current form of a pledge of allegiance contains the words "one nation, under God." Although the Federal Constitution does not contain the name of God, the constitutions of the overwhelming majority of the states make acknowledgment of God and a few invoke "the favor and blessing of Almighty God" or "His blessing." 32

${ }^{29}$ Ibid., p. 45.

${ }^{30}$ Perry, op. cit., p. 203.

${ }^{31}$ Niebuhr, op. cit., p. 80.

${ }^{32}$ Charles Kettleborough, The State Constitutions and the Federal Constitution and 
A third contribution was the value of the individual as a creation of God and as a potential child of God. This, too, was not uniquely Protestant, but it was enhanced by the distinctive Protestant belief in salvation by faith alone, the priesthood of all believers, and the right and duty of individual judgment.

As a corollary, especially among those Protestants who carried the principle to its logical conclusion, this meant, as a fourth contribution, the principles of democratic government as held in the United Statesthat governments hold their just powers from the consent of the governed, the election of civil officials by the suffrage of the citizens and of ecclesiastical officials by church members, the right of the populace to change its form of government, the right and duty of rebellion if the rights were violated, and responsibilities of citizens as well as rights.

In close association with political democracy, went, as a fifth contribution, what has sometimes been called rugged individualism. It was seen in economic and social life. Often it violated Christian ideals in a ruthless exploitation of the weak, but again and again it was accompanied by a deep sense of public responsibility. Sometimes it has been ascribed to the impress made on the American spirit by pioneering on the westward moving frontier and to the self-reliance and initiative bred by the effort to go west and to win a place in a new society. Yet the frontier did not evoke that quality in the emphatically nonProtestant French Canada. The particular kind of individualism combining self-reliance with mutual helpfulness and spontaneous initiative in organizing democratic institutions seems to have been nurtured by the Protestant tradition, attenuated though it often was.

A sixth contribution, also as a corollary to the value of the individual, was religious liberty. As we have seen, much of this came from profound conviction-partly among minority groups, especially the Quakers, Baptists, and Presbyterians, and partly from John Locke and others from the Puritan background. Some was from the Great Awakening, for it multiplied those who dissented from the established churches in New England and the Southern colonies. Much also was from the multiplicity of differing religious bodies and the opposition from those not established to the privileged position of the establishments. Not a little was from the religious indifference of the un-

Organic Laws of the Territories and Other Colonial Dependencies of the United States of America (Indianapolis, 1918), pp. 55, 89, 120, 237, 283, 351, 381, 413, 430, 448, 466, 501, $612,654,685,738,816,923,937,1021,1174,1203,1220,1256,1352,1441,1540$. 
churched and from the Enlightenment. ${ }^{33}$ Some, too, was from the conviction put into words by John Robinson, pastor in Holland of the congregation which laid the foundations of Plymouth Colony but who himself never set foot in the New World, that "God hath [ [caused] more light and truth to break forth out of His Holy Word." ${ }^{34}$ The first amendment to the Constitution of the United States forbade Congress to make a law respecting any establishment of religion or prohibiting the free exercise of religion. The individual states were not placed under such a prohibition, but before the middle of the nineteenth century the last trace of legal preference to any denomination in states where it had existed had been removed.

A seventh contribution and one which followed from the value placed on the individual was in education. Puritanism held to the importance of education, and for every one. Under its impulse, Massachusetts set as a goal compulsory primary education for all. This was the ideal proclaimed by Jefferson, although he did not draw his inspiration as directly from Puritanism. ${ }^{35}$ Increasingly the primary schools were free from ecclesiastical control. So, too, with secondary and higher education. Most of the secondary schools and all but one of the colleges founded before 1776 were begun by Protestants from religious motives. The single seeming exception, what became the University of Pennsylvania, traces its origin to a charity school begun by Whitefield. Several of the schools and colleges, among them the later Princeton University, were outgrowths of the Great Awakening. Yet in all of them ecclesiastical control has been progressively weakened and freedom of thought, teaching, and investigation permitted to proceed unhampered by a church. This again follows from the nature of Protestantism and its belief in the worth and freedom of the individual. With it goes the danger of secularization, but that, as Protestants believe, is the risk which God deliberately took in the Incarnation.

Still another and eighth contribution which colonial Protestantism made to the later United States, and also a corollary to the worth of the individual and the kind of liberty which makes the Christian man the most free man of all and yet the most dutiful servant of all, was in the burgeoning of many forms of both public and private philanthropy. Much of this might be assigned to Christianity in general rather than to Protestantism. Yet in the United States for the most part philanthropy supported by the government is free from ecclesi-

\footnotetext{
${ }^{33}$ Stokes, op. cit., I, 222 ff., $240 \mathrm{ff}$.

s* Perry, op. cit., p. 355.

${ }^{36}$ Perry, op. cit., pp. 193, 194; Brockunier, op. cit., p. vii.
} 
astical control, and while much of the private philanthropy has been through the churches, both Protestant and Roman Catholic, an increasing proportion has been through non-ecclesiastical channels and free from ecclesiastical domination. Much of this must be ascribed to the Protestant tradition.

Along with the spirit of philanthropy has gone a deep sense of mission which has included but has been more inclusive than philanthropy. It is associated with what was seen in the Great Awakeningan effort to win to the faith the non-Christian elements in the population and to carry the Gospel to the Indians on the frontier, and then around the world. It is also symbolized in the Statue of Liberty enlightening the world which, a gift of France, is a recognition of a distinctive quality of the United States-by example rather than by force to encourage the kind of freedom which is the American dream and which is chiefly derived from Christianity in its Protestant form.

In conclusion it may be said that the ideals and forms of life, both private and in government, which have characterized the United States have been deeply indebted to the kind of Protestantism which was vigorous in the colonial period. The United States has not fully conformed to that Protestantism, but more than to any other force to the Protestantism which prevailed in the Thirteen Colonies can be traced many of the dominant features of the ethos of the United States of the nineteenth and twentieth centuries.

Yale University,

KenNeth Scott Latourette

New Haven, Connecticut 